УДК: 316.32:339.3(477)

Свидрук I. I.,

irena_svidruk@ukr.net, ORCID ID:0000-0002-3099-6449,

Researcher ID: F-8502-2019

д.е.н., проф., професор кафедри менеджменту, Львівський торговельно-економічний університет, м. Львів

Клепанчук О. Ю.,

o.klepanchuk@gmail.com,ORCID ID: 0000-0001-7764-614X

к.е.н., дои., доцент кафедри фінансового менеджменту, Львівський національний університет імені Івана Франка, м. Львів

\title{
ГЛОБАЛІЗАЦІЙНІ ОСОБЛИВОСТІ РОЗВИТКУ ВНУТРІШНЬОГО РИНКУ УКРАЇНИ
}

\begin{abstract}
Анотація. Статтю присвячено виявленню та узагальненню передумов інституційного регулювання розвитку внутрішнього ринку України в умовах глобалізації. Проаналізовано соціально-економічні дисбаланси, ияо призвели до погіршення платоспроможного попиту, бюджетного дефіциту $i$ банківської кризи в Украӥні. Встановлено, щчо процеси інтеграції та глобалізації видозмінюють характер економічних відносин, масштабуючи основні ринкові механізми, базовані на поділі пращі на площину світового ринку, в якому діють не тільки економічні, але й соціальні, політичні важелі, щее більще поглиблюючи процеси поділу праці в нових формах їх сучасного прояву, таких як спеціалізація, концентрація, кооперація. Виявлено, щзо інкорпорування фундаментальних правил СОТ дозволило розширити внутрішній ринок Украӥни. Недостатню ефективність інституційних факторів впливу на якість функціонування внутрішнього ринку підтверджено слабкими позиціями Украӥни у міжнародних рейтингах. Проаналізовано трансформацію інституційних засад сочіального забезпечення, спрямованих на подолання бідності і зростання рівня доходів населення, визначено їх позитивний вплив на покращення системи соціальної безпеки. Висвітлено інституційні програми реформування, розроблені за сприяння Світового банку і МВФ. Показано, щуо найбільший позитивний вплив на розвиток внутрішнього ринку здійснили: відмова від валютного регулювання, податкова консолідація, вдосконалення управління державними інвестиціями, персоналізація соціальної підтримки, спрощення умов ведення бізнесу, запровадження податкових методів антикризового регулювання. Зроблено висновок, щүо інституційні фактори впливу на ефективність функціонування внутрішнього ринку використовуються недостатньо ефективно. Подальші дослідження запропоновано скерувати на детальний аналіз інституційних інструментів активізацї функціонування внутрішнього ринку Украӥни.
\end{abstract}

Ключові слова: ринкові засади господарювання, сталий розвиток, інституційне регулювання, конкуренція, оподаткування, соціальна безпека.

Svydruk I. I.,

irena_svidruk@ukr.net, ORCID ID:0000-0002-3099-6449,

Researcher ID: F-8502-2019

Doctor of Economics, Professor, Professor of the Department of Management, Lviv University of Trade and Economics, Lviv, Ukraine

Klepanchuk O. Yu., o.klepanchuk@gmail.com, ORCID ID:0000-0001-7764-614X

Ph.D., Associate Professor of the Department of Accounting and Taxation, Ivan Franko National University of Lviv, Lviv

\section{GLOBALIZATION PECULIARITIES OF THE DEVELOPMENT OF THE DOMESTIC MARKET OF UKRAINE}

\footnotetext{
Abstract. The article is devoted to the identification and generalization of the prerequisites for institutional regulation of the domestic market development in Ukraine in the context of globalization. Socio-economic imbalances that led to the deterioration in effective demand, budget deficit and banking crisis in Ukraine are analyzed. It is determined that the processes of integration and globalization change the nature of economic relations, scaling the main market mechanisms based on the division of labor on the world market, which operates not only economic but also social, political
} 
levers, further deepening the division of labor in new forms of their modern manifestation, such as specialization, concentration, cooperation. It was found that the incorporation of the fundamental rules of the WTO allowed to expand the domestic market of Ukraine. Insufficient efficiency of institutional factors influencing the quality of functioning of the domestic market is confirmed by Ukraine's weak positions in international rankings. The transformation of the institutional foundations of social welfare aimed at overcoming poverty and increasing the level of public income is analyzed as well as their positive impact on the improvement of the social security system is determined. Institutional reform programs developed with the assistance of the World Bank and the IMF are highlighted. It is shown that the greatest positive impact on the development of the domestic market was carried through: rejection of currency regulation, tax consolidation, improvement of public investment management, personalization of social support, simplification of conditions for doing business, introduction of tax methods of anti-crisis regulation. It is concluded that the institutional factors influencing the efficiency of the domestic market are not used effectively enough. Further research is proposed to focus on a detailed analysis of institutional tools for activating the domestic market functioning in Ukraine.

JEL Classification: L16, L17, L51, P23

DOI: https://doi.org/10.36477/2522-1205-2021-62-17

Постановка проблеми. В глобалізованому світовому просторі український внутрішній ринок відзначається доволі високим ступенем торговельної відкритості, що зумовлює узалежненість його розвитку від змін на зовнішніх ринках і визначає основні орієнтири структурної реорганізації. Світова фінансова криза змінила умови соціальноекономічного розвитку провідних країн світу, переорієнтувавши усталені тенденції еволюції податкової політики. Глобальна економіка вступила у фазу Industry 4.0, якій притаманні якісні зміни у системі факторів суспільного відтворення. Наявність протиріч між існуючими ринковими реаліями та неоліберальними концепціями ринкової досконалості актуалізує завдання мінімізації уразливості розвитку внутрішнього ринку. Розвиток внутрішнього ринку потребує інституціонального вирішення фінансових, організаційно-правових, інформаційних проблем його суб'єктів, водночас забезпечуючи прогресивний розвиток, стабільність, стійкість та економічний прогрес держави. Довгострокова позитивна динаміка економічного розвитку держави вимагає стабільності та стійкої економічної незалежності всіх секторів ринку. Актуалізуються питання інституційного впливу на всі процеси стратегічного планування і реалізації структурної політики, засадничими принципами якого $є$ динамічна об'єктивізація структури національної економіки, відповідність структурної перебудови наявному економічному потенціалу держави, можливість отримання синергетичного ефекту від поєднання програм структурних зрушень окремих ринкових сегментів, орієнтація на цільові структурні зміни, полікритеріальність цілей структурного реформування.

Аналіз останніх досліджень і публікацій. Проблемам оновлення вітчизняного ринкового простору присвячено значну низку наукових досліджень. Так, М. В. Чорна та співавт. виокремили три ісрархічні рівні впливу чинників створення принципово нового ринкового простору на засадах блакитного океану. Запропонований авторами комплексний підхід у перспективі передбачає можливість чіткого оцінювання макроекономічної ситуації, виявлення можливостей стратегічної трансформації внутрішнього ринку і розроблення відповідних управлінських важелів [13]. Разом 3 тим, подібна концептуалізація викликає певні зауваження щодо доцільності саме такого шляху розвитку ринкового простору, оскільки реалізація стратегії “блакитних океанів" значно посилює ринкові ризики, викликані взаємовиключенням іiі засадничих положень на різних етапах розвитку внутрішнього ринку. Попри це, нам представляється надзвичайно важливою запропонована науковцями модель диференціації потенційних підприємств ініціаторів створення нових ринкових просторів.

Класичний напрямок дослідження ринків відображено у науковій праці Н. М. Попадинця, який аргументовано доводить, що функціонування та розвиток внутрішнього ринку має спиратися на певну систему завдань, функцій і методологічних принципів, що відображають основні його закономірності, а реформування його сегментів і поява конкуренції змінюють усталені принципи і методи управління [10]. Методологічні принципи функціонування ринку автор поділяє на три групи: загальноекономічні (соціальної орієнтації, системності, ефективності, саморегулювання, цільового управління), організаційно-технологічні (ієрархічності, поділу праці, оптимального співвідношення централізації і децентралізаціі) і специфічні (варіантності, пріоритетності, збалансованості, функціональної інтеграції, доцільності і конкуренції), справедливо зазначаючи, що лише цілісне їх застосування може забезпечити якісний розвиток ринку.

Т. П. Яхно зазначає, що постіндустріальне суспільство характеризується якісними змінами в матеріальних умовах життя людини [14]. Саме 3 цим автор пов'язує якісні зміни споживчого ринку, що проявляються зростанням масштабів виробництва, підвищенням якості і осучасненням продукції, появою соціально-орієнтованих інноваційних продуктів та глобалізацією споживачів.

Ю. М. Уманців та М. В. Катран здійснили глибокий аналіз тенденцій розвитку внутрішнього ринку України і дійшли висновку про наявність прогалин інституційного характеру, що призвели до недосконалої цінової конкуренції, скорочення частки товарів кінцевого споживання в структурі 


\section{Herald of Lviv University of Trade and Economics. Economic Sciences. № 62, 2021}

сукупної пропозиції, збільшення надходжень інноваційних товарів імпортного походження [11]. Варто погодитися 3 висновками авторів щодо необхідності підвищення ефективності ринкового нагляду та контролю якості продукції, тим більше, що пропозиції науковців обгрунтовані аналізом досвіду країн СС у даній царині.

К. С. Колеснікова, Т. С. Руденко вивчали особливості розвитку ринку в умовах розгортання економічної кризи і дійшли висновку, що ефективним інструментом виходу з кризи є поєднання ресурсів держави та бізнесу за збереження стратегічно важливих об'єктів державної власності [6]. На сьогодні пріоритетними напрямками вдосконалення інфраструктури ринку ці науковці називають нормативно-правове, економічне та адміністративне стимулювання підприємницької активності та потенційних інвесторів.

А. Е. Халілов здійснив дослідження основних тенденцій, пов'язаних із розподілом на ринку споживання [12]. На підставі аналізу статистики системи споживання в розрізі регіонів України автор доходить висновку, що економічна політика покликана передбачити дії учасників ринку, виходячи із задач їх максимальної збалансованості та доцільності.

В. Б. Громов зауважує, що досягнення макроекономічної стабільності вимагає балансування між споживчим попитом та обсягами пропозиції. Автор надає ряд рекомендацій щодо державних механізмів регулювання внутрішнього ринку, зазначаючи, що прямий вплив на споживчий попит держава має здійснювати через соціальну політику, опосередкований - через розвиток підприємництва і підтримку окремих галузей [2]. Підтримуючи таку наукову позицію автора, підкреслимо, що його висновки грунтуються на розумінні механізмів впливу соціалізації економіки на функціонування ринку, балансі між ринковою ефективністю і соціальною справедливістю.

Отож, можна стверджувати, що вітчизняними науковцями ведуться активні пошуки інструментів активізації внутрішнього ринку України, однак опубліковані в останні роки дослідження мають доволі секторальний характер, тоді як нагальна необхідність його структурної реорганізації вимагає системного аналізу всіх аспектів інституційного забезпечення розвитку ринку.

Постановка завдання. Метою даного дослідження $є$ узагальнення передумов інституційного регулювання розвитку внутрішнього ринку України в умовах глобалізації.

Виклад основного матеріалу дослідження. Внутрішній ринок є важливим структурним елементом ринкової економіки, адже в його межах відбувається перерозподіл споживаної частини суспільного продукту. В сучасних економічних умовах внутрішній ринок є відображенням структури та стану економічної системи країни, розвитку ii суспільних відносин та соціально-економічних процесів.

Основними об'єктами внутрішнього ринку виступають сегменти ринку, ринкова кон'юнктура, попит та пропозиція, ринкові процеси, процеси взаємодії між сегментами ринку, матеріальні потоки: товари, послуги, роботи; фінансові потоки; інформаційні та комунікаційні потоки. Основними суб'єктами внутрішнього ринку є покупці товарів та послуг, продавці, торгові посередники, в тому числі і нерезиденти, державні законотворчі та регулюючі інституції, організації, що формують ринкову інфраструктуру (логістичні, фінансові, інвестиційні, біржові тощо). Об'єктами державного регулювання $є$ внутрішній ринок як система та його сектори як підсистеми, економічні та соціальноекономічні, ринкові процеси, що відбуваються на внутрішньому ринку та які не можуть бути повною мірою вирішені внутрішніми процесами ринкового регулювання та саморегулювання, такі як відтворювальні процеси, чи процеси взаємодії.

Розвиток споживчого ринку забезпечує безперебійне функціонування ланцюжка споживання за схемою: “формування потреби населення в певному товарі $\rightarrow$ виробництво цього товару $\rightarrow$ грошові доходи населення $\rightarrow$ реалізація товару $\rightarrow$ задоволення потреб споживача". Таким чином, формування споживацької потреби формує заявку на певний обсяг виробництва i зумовлює відповідну структуру виробничих ресурсів (рис. 1).

Разом $з$ тим, процеси інтеграції та глобалізації видозмінюють характер економічних відносин, масштабуючи основні ринкові механізми, базовані на поділі праці на площину світового ринку, в якому діють не тільки економічні, але й соціальні, політичні важелі, ще більше поглиблюючи процеси поділу праці в нових формах їх сучасного прояву, таких як спеціалізація, концентрація, кооперація.

У сучасних умовах ефективне функціонування економіки країни, прогнозування та планування ii економічного та соціального розвитку потребує застосування засобів та механізмів активного державного регулювання. Недостатність структурного реформування призвела у 2014-2015 рр. до виникнення безпрецедентної кризи на внутрішньому ринку України. Стрімке падіння цін на товарну продукцію на світових ринках послабило позиції України на зовнішніх ринках, зменшення реального ВВП у 2014 р. сягало 6,6 \%, у 2015 р. - ще 9,8\% [3]. Накопичений соціально-економічний дисбаланс спричинив до необхідності суттєвого бюджетного коригування, що додатково погіршило попит на внутрішньому ринку. Відбулося стрімке знецінення гривні (у 2014 р. - на 47 \%, у 2015 р. - ще на $33 \%$ відносно долара США), дефіцит консолідованого державного бюджету в 2014 р. сягнув позначки $10,1 \%$ ВВП [3], рецесія призвела до банківської кризи, спричиненої відпливом депозитів і зростанням частки проблемних кредитів. При цьому спостерігалася тенденція зростання відношення гарантованого державою боргу до ВВП. Програми реформування, розроблені за сприяння Світового банку і МВФ, дозволили зменшити описані дисбаланси і до певної міри стабілізувати внутрішній ринок. Починаючи з 2016 р., відбувалося поступове поліпшення інвестиційного клімату, чому сприяли покращення фінансових результатів господарської 
діяльності суб'єктів внутрішнього ринку, прискорення темпів реалізації енергозберігаючих проектів, зростання рівня ділових очікувань (на 16,2% у 2019 р.). Зростання ефективності діяльності з відповідним нарощуванням валової доданої вартості відбулося в хімічній промисловості, машинобудуванні, сфері ІТ-послуг, агропромисловості. Водночас темпи споживчої інфляції поступово сповільнювались і у 2019 р. демонстрували найнижче значення у періоді 2014-2019 pp. (4,1 \%).

Внутрішній товарний ринок України представлений переважною наявністю приватної власності на засоби і результати виробництва, тоді як частка суб'єктів господарювання державного сектору складала у 2019 р. лише 4,6 \% (табл. 1).

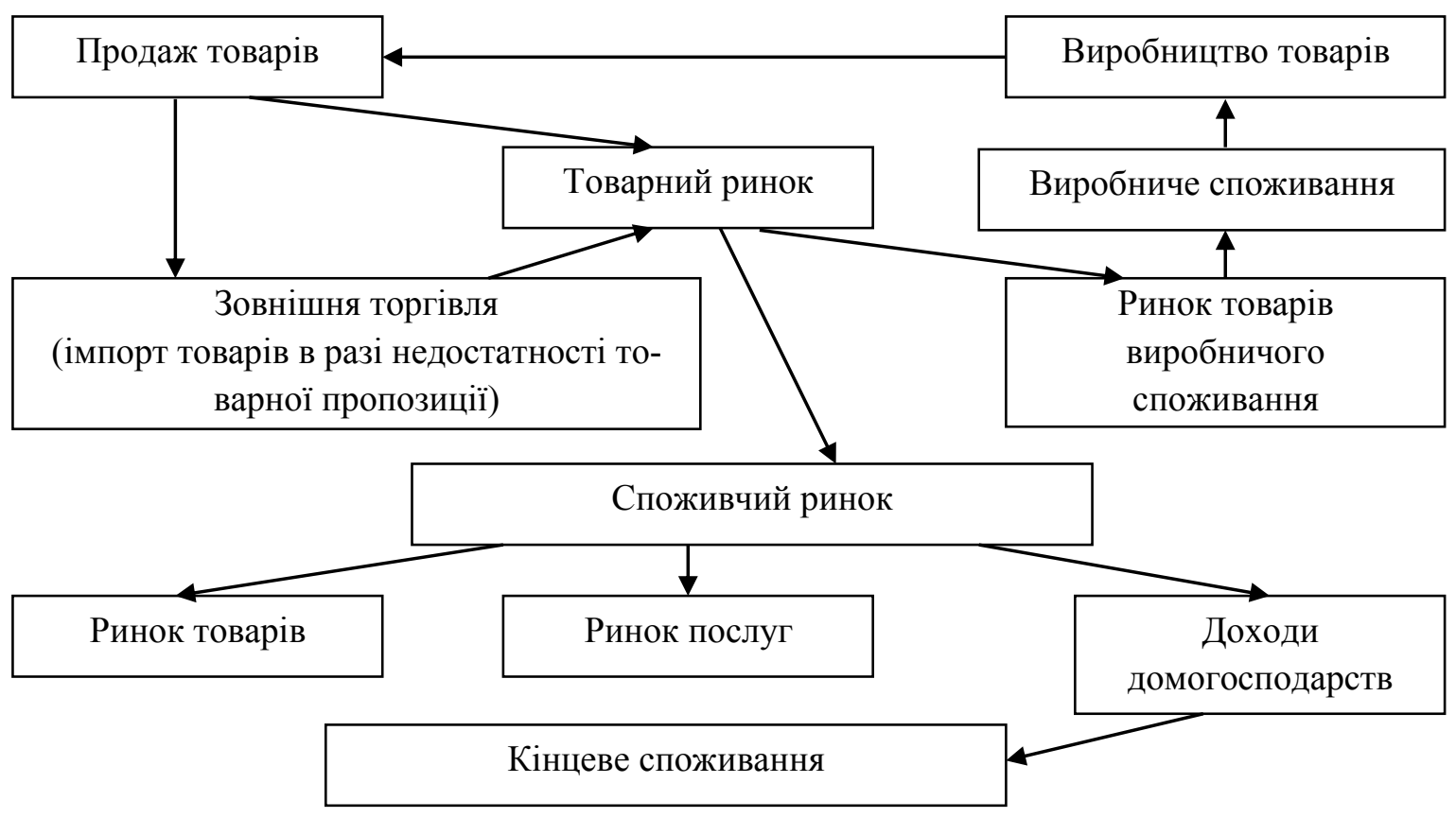

Рис. 1. Функціональні взаємозв'язки внутрішнього ринку

Джерело: власна розробка

Табличя 1

Частка державної участі у складі суб'сктів внутрішнього товарного ринку України у 2019 р.

\begin{tabular}{|l|c|c|c|c|}
\hline \multicolumn{1}{|c|}{ Вид економічної діяльності } & $\begin{array}{c}\text { Частка суб'єктів } \\
\text { господа- } \\
\text { рювання, } \%\end{array}$ & $\begin{array}{c}\text { Частка } \\
\text { доходу від } \\
\text { реалізації, } \%\end{array}$ & $\begin{array}{c}\text { Частка } \\
\text { вартості } \\
\text { активів, \% }\end{array}$ & $\begin{array}{c}\text { Частка державного } \\
\text { сектору внутрішнього } \\
\text { ринку, \% }\end{array}$ \\
\hline Усього, у т.ч.: & 4,6 & 10,7 & 21,4 & 12,2 \\
\hline Сільське господарство & 3,3 & 0 & 0,9 & 1,4 \\
\hline Промисловість & 6,7 & 0,1 & 0,2 & 0,2 \\
\hline Будівництво & 0,4 & 0,9 & 1,4 & 29,0 \\
\hline Оптова та роздрібна торгівля & 0,6 & 37,7 & 43,4 & 7,6 \\
\hline $\begin{array}{l}\text { Транспорт, складське } \\
\text { господарство }\end{array}$ & 8 & 1,7 & 9,7 & 5,8 \\
\hline Готельно-ресторанний бізнес & 11,4 & 2,1 & 6,6 & 0,6 \\
\hline Інформація та телекомунікації & 8,6 & 0,3 & 0,4 & 2,0 \\
\hline $\begin{array}{l}\text { Фінансова та страхова } \\
\text { діяльність }\end{array}$ & 1,1 & 1,1 & 1,6 & 59,9 \\
\hline Операції з нерухомим майном & 3,2 & 79,1 & 80 & 1,3 \\
\hline $\begin{array}{l}\text { Професійна, наукова та техніч- } \\
\text { на діяльність }\end{array}$ & 20,5 & 0,4 & 0,9 & - \\
\hline $\begin{array}{l}\text { Адміністративне } \\
\text { обслуговування }\end{array}$ & 2,7 & 0 & - & 2,7 \\
\hline Освіта & - & 7,5 & 49,9 & 32,5 \\
\hline $\begin{array}{l}\text { Охорона здоров’я та соціальна } \\
\text { допомога }\end{array}$ & 3,2 & 40 & 4,4 & \\
\hline Мистецтво, спорт, відпочинок & & & \\
\hline
\end{tabular}

Джерело: розраховано за даними [3] 
Дослідження взаємозв'язків між суб'єктами внутрішнього ринку передбачає використання таких макроекономічних індикаторів ефективності, як валовий внутрішній продукт, валовий національний дохід, чистий внутрішній продукт, національний дохід та особистий дохід у розпорядженні внутрішнього ринку. Аналіз валового внутрішнього продукту передбачає визначення сукупного обсягу діяльності ринкових суб'єктів, який не включає проміжне споживання. Цей індикатор, що оцінюється як загальна ринкова вартість кінцевої продукції, виробленої резидентами за рік, дозволяє об'єктивно визначити рівень і темпи економічного розвитку і продуктивності суспільної праці. Його також покладено в основу визначення інших макропоказників ефективності внутрішнього ринку, зокрема валового національного доходу. Дослідження динаміки макроекономічних індикаторів у цілому та в розрізі їх окремих складових дозволяє оцінити тенденції економічного зростання, стагнації або спаду внутрішнього ринку та передбачити необхідність структурних зрушень в економічній системі (табл. 2). Так, серед основних реформ, здійснених після 2014 р., найбільший вплив на внутрішній ринок мали запровадження гнучкого валютного курсу, фіскальна консолідація, вдосконалення системи державних закупівель та управління державними інвестиціями, стабілізація банківського сектора, реформування у сфері тарифікації енергопостачання, персоналізація соціальної підтримки, спрощення умов ведення бізнесу та впровадження низки антикорупційних інструментів.

Ратифікована Україною у 2014 р. Угода про асоціацію з СС [1] розширила можливості реформування українського внутрішнього ринку та модернізації економічного розвитку, створивши умови для гармонізації українських законів, норм та стандартів із тими, що діють у СС у різних ринкових секторах. Водночас варто зауважити про фактор деіндустріалізації вітчизняного внутрішнього ринку, яким було зумовлено небезпечну для України технологічну диспропорційність.

Таблиия 2

Макроекономічні індикатори розвитку України у 2014-2019 рр.

\begin{tabular}{|c|c|c|c|c|c|c|c|}
\hline Показник & 2014 & 2015 & 2016 & 2017 & 2018 & 2019 & $\begin{array}{c}2019 / \\
2014, \% \\
\end{array}$ \\
\hline $\begin{array}{l}\text { Обсяг реалізованої промислової } \\
\text { продукції, млрд грн }\end{array}$ & 1066,8 & 1351,4 & 1565,3 & 1926,9 & 2261,6 & 2272,7 & 213,0 \\
\hline Індекс промислової продукції & 89,3 & 86,6 & 102,4 & 99,9 & 101,1 & 98,2 & 110,0 \\
\hline $\begin{array}{l}\text { Індекс цін виробників промисло- } \\
\text { вої продукції }\end{array}$ & 131,8 & 136 & 120,5 & 126,4 & 117,4 & 104,1 & 79,0 \\
\hline $\begin{array}{l}\text { Обсяг сільськогосподарської } \\
\text { продукції, млрд грн }\end{array}$ & 370,8 & 544,2 & 631,1 & 690,9 & 843,3 & 840,6 & 226,7 \\
\hline $\begin{array}{l}\text { Індекс сільськогосподарської } \\
\text { продукції }\end{array}$ & 97,4 & 95,2 & 106,1 & 97,3 & 107,8 & 101,1 & 103,8 \\
\hline $\begin{array}{l}\text { Обсяг виробленої будівельної } \\
\text { продукції, млрд грн }\end{array}$ & 50,2 & 55,9 & 70,9 & 101,1 & 136,3 & 177,0 & 352,6 \\
\hline Індекс будівельної продукції & 78,3 & 85,1 & 113,1 & 120,9 & 104,4 & 126,8 & 161,9 \\
\hline $\begin{array}{l}\text { Оборот роздрібної торгівлі, млрд } \\
\text { грн }\end{array}$ & 903,5 & 1018,8 & 1159,3 & 816,6 & 928,6 & 1096,7 & 121,4 \\
\hline Вантажообіг, млрд т/км & 335,2 & 315,3 & 323,5 & 343,1 & 331,7 & 338,9 & 101,1 \\
\hline $\begin{array}{l}\text { Пасажирообіг, } \\
\text { млрд пас.км }\end{array}$ & 106,1 & 97,3 & 102,2 & 99,3 & 103,8 & 107,9 & 101,7 \\
\hline Індекс споживчих цін & 124,9 & 148,7 & 113,9 & 114,4 & 110,9 & 107,9 & 86,4 \\
\hline $\begin{array}{l}\text { Середньомісячна номінальна } \\
\text { заробітна плата одного праців- } \\
\text { ника, грн }\end{array}$ & 3476 & 4195 & 5070 & 7104 & 8865 & 10497 & 302,0 \\
\hline Реальна заробітна плата, \% & 93,5 & 79,8 & 78,9 & 119,1 & 112,5 & 109,8 & 117,4 \\
\hline $\begin{array}{l}\text { Заборгованість із виплати за- } \\
\text { робітної плати, млн грн }\end{array}$ & 2436,8 & 1880,8 & 2004 & 2368,4 & 2645,1 & 3034,4 & 124,5 \\
\hline $\begin{array}{l}\text { Експорт товарів, } \\
\text { млрд дол. США }\end{array}$ & 53,9 & 38,1 & 36,4 & 43,3 & 47,3 & 50,1 & 92,9 \\
\hline $\begin{array}{l}\text { Імпорт товарів, } \\
\text { млрд дол. США }\end{array}$ & 54,4 & 37,5 & 39,2 & 49,6 & 57,2 & 60,8 & 111,8 \\
\hline $\begin{array}{l}\text { Сальдо }(+,-), \\
\text { млрд дол. США }\end{array}$ & $-0,5$ & 0,6 & $-2,9$ & $-6,3$ & $-9,9$ & $-10,7$ & 2140,0 \\
\hline
\end{tabular}

Джерело: розраховано за даними [3] 
Лібералізація ринкових засад господарювання спричинила до загострення конкуренції на внутрішньому ринку України, визначивши можливі ризики посилення конкурентного тиску, витіснення національного виробника, необхідності пошуку інвесторів для модернізації виробництв.

Водночас макроекономічна ситуація у 20142019 рр. залишалася доволі уразливою, дефіцит державного бюджету на кінець відповідного року становив: 2014 р. - 40,1 млрд грн, 2015 р. 30,9 млрд грн, 2016 р. - 63,4 млрд грн, 2017 р. 42,1 млрд грн, 2018 р. - 7,3 млрд грн, 2019 р. 20,7 млрд грн. Практично за всіма статтями державний бюджет на 2019 р. було недовиконано. Доходи були виконані на 99,1\%: 3 очікуваних 1007,3 млрд грн було отримано 998,3 млрд грн. У 2019 р. фінансування державного бюджету було заплановано на рівні 91,1 млрд грн, однак реальне фінансування відбулося на рівні 81 млрд грн (88,9 \%). Витрати планувалися на рівні 1093 млрд грн, однак фактично склали 1075,1 млрд грн $(98,4 \%)$ [8]. Для поліпшення ситуації з державним бюджетом застосовувалися здебільшого інструменти короткострокового впливу, зокрема жорстке контролювання номінальних видатків i впровадження надзвичайних податкових заходів. Разом 3 тим, упродовж останніх років тенденції податкової політики України набули якісно нових ознак: призупинилися процеси послідовної лібералізації оподаткування, співвідношення між податковими надходженнями до бюджету змінилося на користь непрямих податків і податків на соціальне страхування. Недостатня ефективність податкового регулювання обумовлена інституціональними деформаціями як у фінансовій системі, так і в інших сферах суспільного життя.

Аналіз стану та механізмів реалізації податкової політики в сучасній глобалізованій економіці дозволяє виокремити універсальні податкові методи антикризового регулювання, які набувають певних особливостей 3 огляду на структурні відмінності національних економік. Податкове законодавство гармонізоване для всіх країн ЄС і включає обов'язкові заходи 3 блокування можливостей мінімізації оподаткування, інструменти запобігання зловживанням та обмін податковою інформацією. У сукупності ці заходи повинні перешкоджати мінімізації податкових зобов'язань, сприяти підвищенню прозорості та забезпечити справедливі умови для підприємств на загальному ринку.

В Україні у 2014-2019 рр. коефіцієнт навантаження за прямими податками (податок на прибуток, ПДФО, податок на нерухоме майно, плата за землю, єдиний, транспортний, екологічний податки) знаходився в діапазоні 1,8-5,3\%. Коефіцієнт навантаження за непрямими податками, які включають ПДВ, акцизні податки, ввізне та вивізне мито, у 2020 р. знаходився в діапазоні 10,8-14,2\% (рис. 2). Помітним $є$ перерозподіл податкового навантаження в сторону непрямих податків.

Ризикованість чинної системи оподаткування щодо спекулювання податковими ставками зумовила в 2020 р. зміни до Податкового кодексу України [9], які передбачають приєднання до міжнародної програми розширеного співробітництва BEPS і покрокове запровадження контролю за трансфертним ціноутворенням, оподаткування контрольованих іноземних компаній, обмеження витрат за фінансовими операціями з пов'язаними особами, запобігання зловживанням у зв'язку із застосуванням договорів про уникнення подвійного оподаткування, застосування процедури взаємного узгодження.

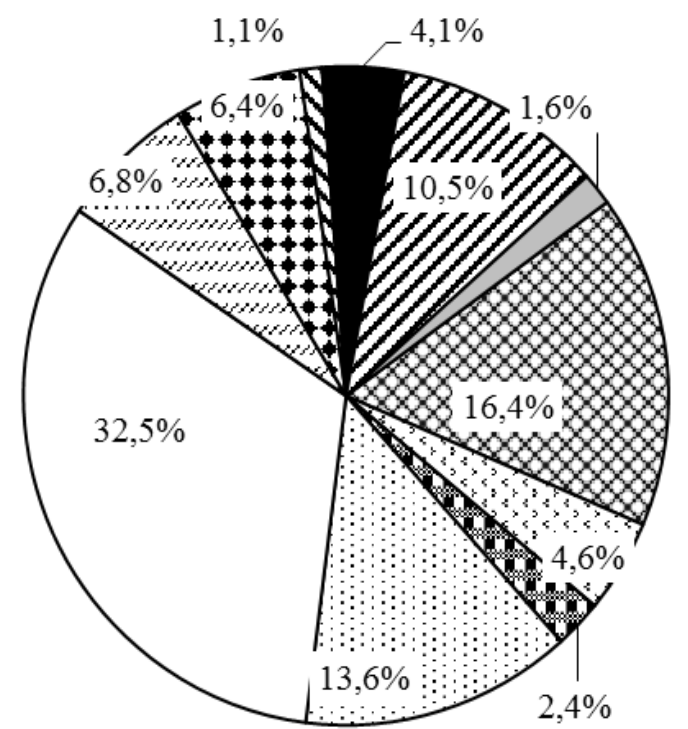

Рис. 2. Структура непрямих податків в Україні у 2020 р.
घПодаток на доходи фізичних осіб

口Податок на прибуток підприємств

Рентна плата за використання природних ресурсів

ФПодаток на додану вартість 3 вітчизняних товарів

口Податок на додану вартість 3 імпортних товарів

๑Акцизний податок з вироблених в Україні товарів

口Акцизний податок з ввезених в Україну товарів

$\mathbf{\boldsymbol { Q }}$ Доходи від власності та підприємницької діяльності

- Інші податки та збори

चІнші неподаткові надходження

口Інше 
Незважаючи на наявність саморегулюючих та регулюючих функцій внутрішнього ринку, прийнятого та діючого в країні нормативно-правового забезпечення та механізмів його дотримання, вагомим для інтенсивного цілеспрямованого розвитку внутрішнього ринку та всіх його структурних сегментів є наявність та дія ефективного і збалансованого механізму державного регулювання внутрішнього ринку країни. Висока значимість трансформації соціального забезпечення і системи соціальної безпеки для розвитку внутрішнього ринку спонукає до аналізу різних аспектів даної проблеми. Соціальна безпека загалом може навіть розглядатися в якості ідентифікатора суспільного сприйняття структурного реформування внутрішнього ринку, адже вона охоплює відносини щодо перерозподілу національного доходу для забезпечення соціальних стандартів в умовах високої невизначеності і ризиків [4], гарантуючи інституційну захищеність соціальних інтересів індивіда, суспільства і держави як основних представницьких категорій споживачів внутрішнього ринку.

Змістову грань субстанціонального рівня соціальної безпеки демонструє співвідношення "соціально-економічні інтереси $\rightarrow$ соціальні загрози”, яке сфокусоване на системному аналізі внутрішніх і зовнішніх детермінант іiі розвитку i дозволяє виявити чинники негативного впливу на функціонування внутрішнього ринку. В
2014-2019 рр. рівень соціальної безпеки в Україні можна охарактеризувати тенденцією помірного зростання (табл. 3), однак коливанням не була притаманна однозначна тенденція зміни. Можна виокремити певне зростання до 2016 р., різке падіння у 2017-2018 pр. і суттєве зростання в 2019 р. (на 10,8\%). Разом $з$ тим, позитивна тенденція чітко простежується лише за трьома субіндексами: матеріальним добробутом, безпекою здоров'я та життя та соціальним включенням, натомість за субіндексами соціально-трудових відносин, демографічної ситуації та соціального захисту рівень соціальної безпеки щороку знижувався.

Спад економіки у 2014-2015 pp., знецінення гривні і скорочення поточних видатків бюджету призвели до зменшення рівня доходів населення і підвищення рівня бідності з 3,3 \% до 5,8 \%, помірна бідність зросла відповідно 3 15,2\% до 22,2 \% за рахунок зниження реальної заробітної плати на $20 \%$ і зростання рівня безробіття до 9,5\%. Найгостріше ці проблеми проявлялися в зоні військового конфлікту на сході України та серед внутрішньо переміщених осіб. До зростання рівня бідності спричинило і підвищення тарифів на житлово-комунальні послуги, попри оновлення державної програми субсидій (у 2017 р. нею було охоплено понад 7 млн українських домогосподарств).

Таблиця 3

Динаміка субіндексів та інтегрального показника рівня соціальної безпеки України у 2014-2019 рр.

\begin{tabular}{|c|c|c|c|c|c|c|c|c|c|c|}
\hline \multirow{3}{*}{ Роки } & \multicolumn{7}{|c|}{ Субіндекси за підсистемами соціальної безпеки } & \multirow{3}{*}{$\sum_{J}^{\pi}$} & \multirow[b]{2}{*}{ 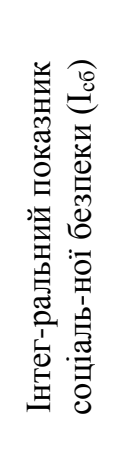 } & \multirow[b]{2}{*}{ 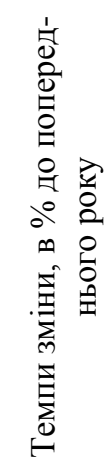 } \\
\hline & 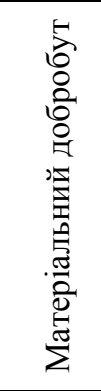 & 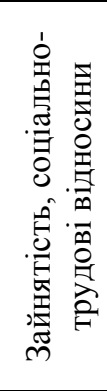 & 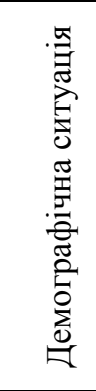 & 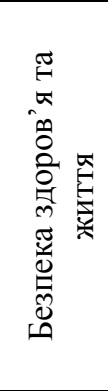 & 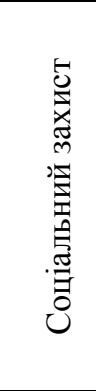 & 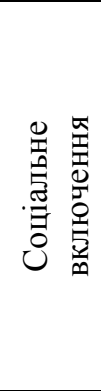 & 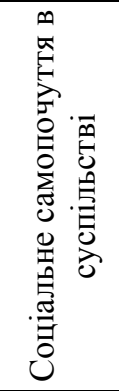 & & & \\
\hline & $\mathrm{I}_{1}$ & $\mathrm{I}_{2}$ & $\mathrm{I}_{3}$ & $\mathrm{I}_{4}$ & $\mathrm{I}_{5}$ & $\mathrm{I}_{6}$ & $\mathrm{I}_{7}$ & & \multicolumn{2}{|c|}{$I_{C Б}=\frac{1}{7} \sum_{i=1}^{7} I_{i}$} \\
\hline 2014 & 0,516 & 0,468 & 0,529 & 0,515 & 0,468 & 0,47 & 0,454 & 3,42 & 0,489 & 2,7 \\
\hline 2015 & 0,519 & 0,508 & 0,566 & 0,518 & 0,478 & 0,567 & 0,425 & 3,581 & 0,512 & 4,9 \\
\hline 2016 & 0,501 & 0,52 & 0,5 & 0,585 & 0,473 & 0,693 & 0,506 & 3,778 & 0,540 & 5,5 \\
\hline 2017 & 0,442 & 0,435 & 0,419 & 0,552 & 0,414 & 0,698 & 0,418 & 3,378 & 0,483 & $-10,74$ \\
\hline 2018 & 0,548 & 0,471 & 0,399 & 0,572 & 0,367 & 0,754 & 0,4 & 3,511 & 0,502 & 4,1 \\
\hline 2019 & 0,677 & 0,565 & 0,342 & 0,731 & 0,437 & 0,773 & 0,369 & 3,894 & 0,556 & 10,8 \\
\hline \multicolumn{11}{|c|}{ Темпи змін, 2019 р. до (у \%): } \\
\hline 2014 & 45,6 & $-15,2$ & $-19,0$ & 42,8 & $-28,9$ & 94,7 & $-34,2$ & - & 6,9 & - \\
\hline 2015 & 30,4 & 11,2 & $-39,6$ & 41,1 & $-8,6$ & 36,3 & $-13,2$ & - & 8,6 & - \\
\hline 2018 & 35,1 & 8,7 & $-14,5$ & 27,8 & 19,1 & 2,5 & $-7,8$ & - & 10,8 & - \\
\hline
\end{tabular}

Джерело: розраховано автором за даними [3] 


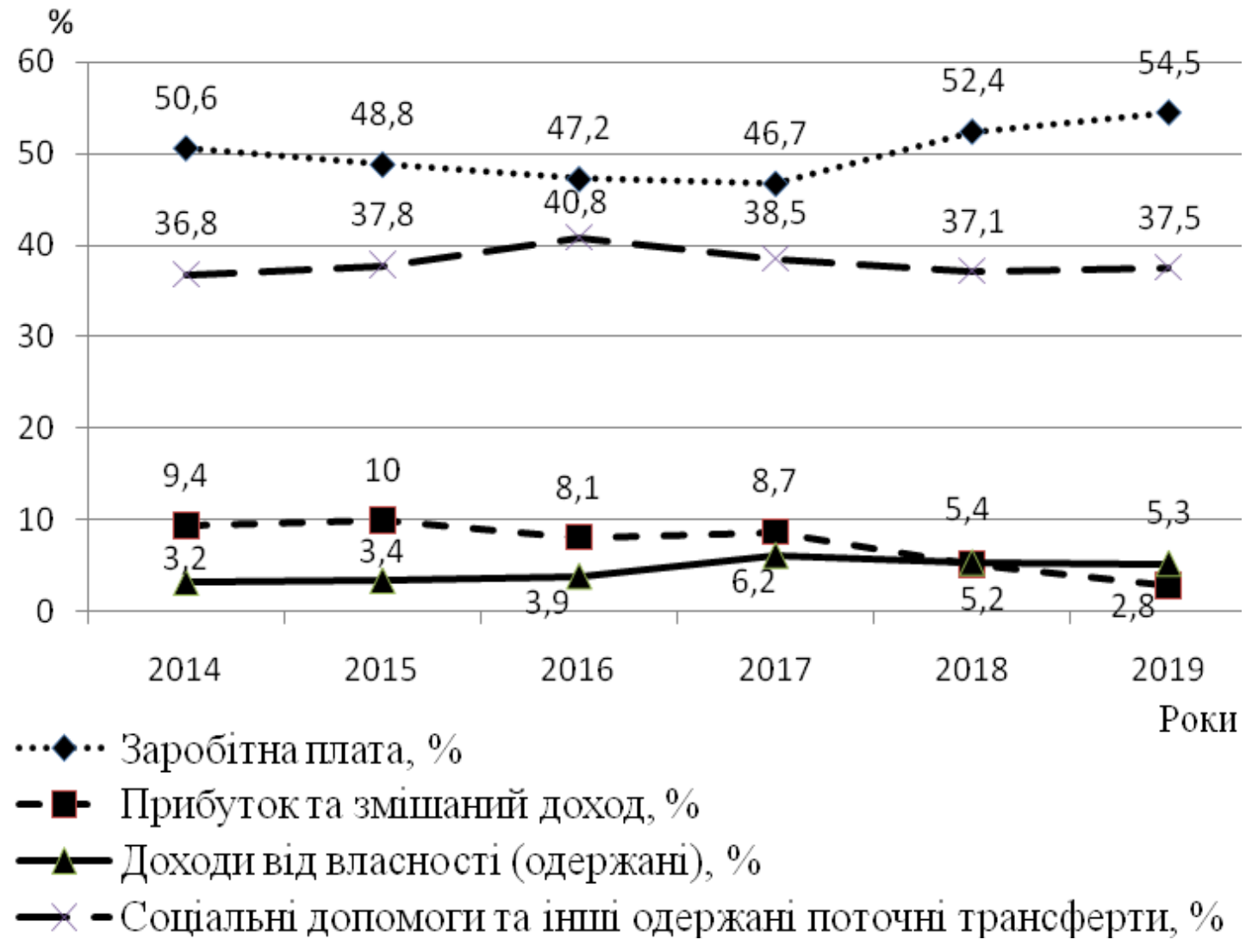

Рис. 3. Структурна динаміка доходів населення України у 2014-2019 рр.

Джерело: розраховано за даними [3]

На подолання проблеми високого рівня бідності була спрямована реалізація державної Стратегії подолання бідності [5] та присднання України до програми ООН "Цілі Сталого Розвитку 2016-2030” [7], цільовими орієнтирами яких є ліквідація абсолютної бідності (5,05 дол. США доходу на добу), зниження до $25 \%$ відносної бідності, скорочення в 10 разів частки осіб, рівень споживання яких $\epsilon$ меншим за рівень фактичного прожиткового мінімуму. Попри це, рівень бідності в Україні у 2019 р. становив 3,5\%, бідності працюючих осіб - близько $20 \%$, відносної бідності - близько $25 \%$, бідності серед дітей - 32,6 \%. Споживання нижче прожиткового мінімуму зафіксовано у 2019 р. на рівні 22,1 \% [3]. Ефективність перерозподільного потенціалу соціальної інфраструктури на макрорівні демонструє розподіл доходів домогосподарств, сформованих з бюджетних соціальних трансфертів (рис. 3).
Одним із інституційних факторів впливу на ефективність функціонування внутрішнього ринку $\epsilon$ ступінь державної підтримки інвестиційної активності бізнесу. Активність внутрішньодержавних інвесторів при надмірному тиску може переорієнтовуватись у бік країн з більш привабливими режимами інвестування. Ризики іноземних інвесторів більше пов'язані зі складністю започаткування бізнесу в Україні та низькою правовою захищеністю інтелектуальних прав. Зокрема, за даними Doing Business-2020 [16], який аналізує інституційні умови сприяння діловій активності в 190 країнах світу, Україна в 2020 р. посідала лише 64 місце (у 2019 р. - 71 місце). Попри покращення таких показників, як отримання дозволів (на 10 пунктів) чи захист міноритарних інвесторів (на 27 пунктів), за більшістю досліджуваних характеристик спостерігається незначне покращення, а за умовами оподаткування - погіршення на 11 пунктів (рис. 4). 


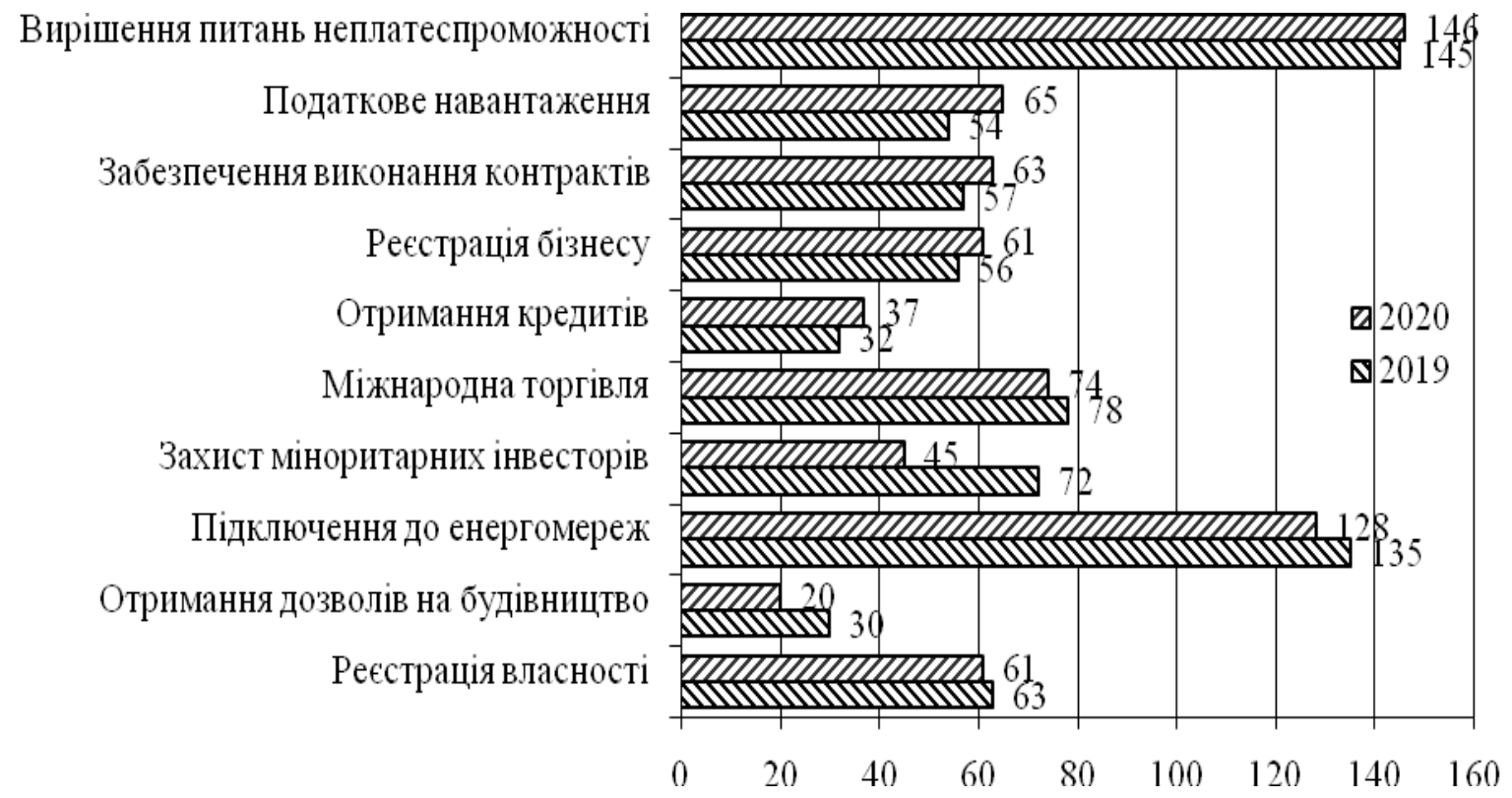

3

Рис. 4. Динаміка рейтингових позицій України щодо інституційного регулювання ведення бізнесу в 2019-2020 рр.

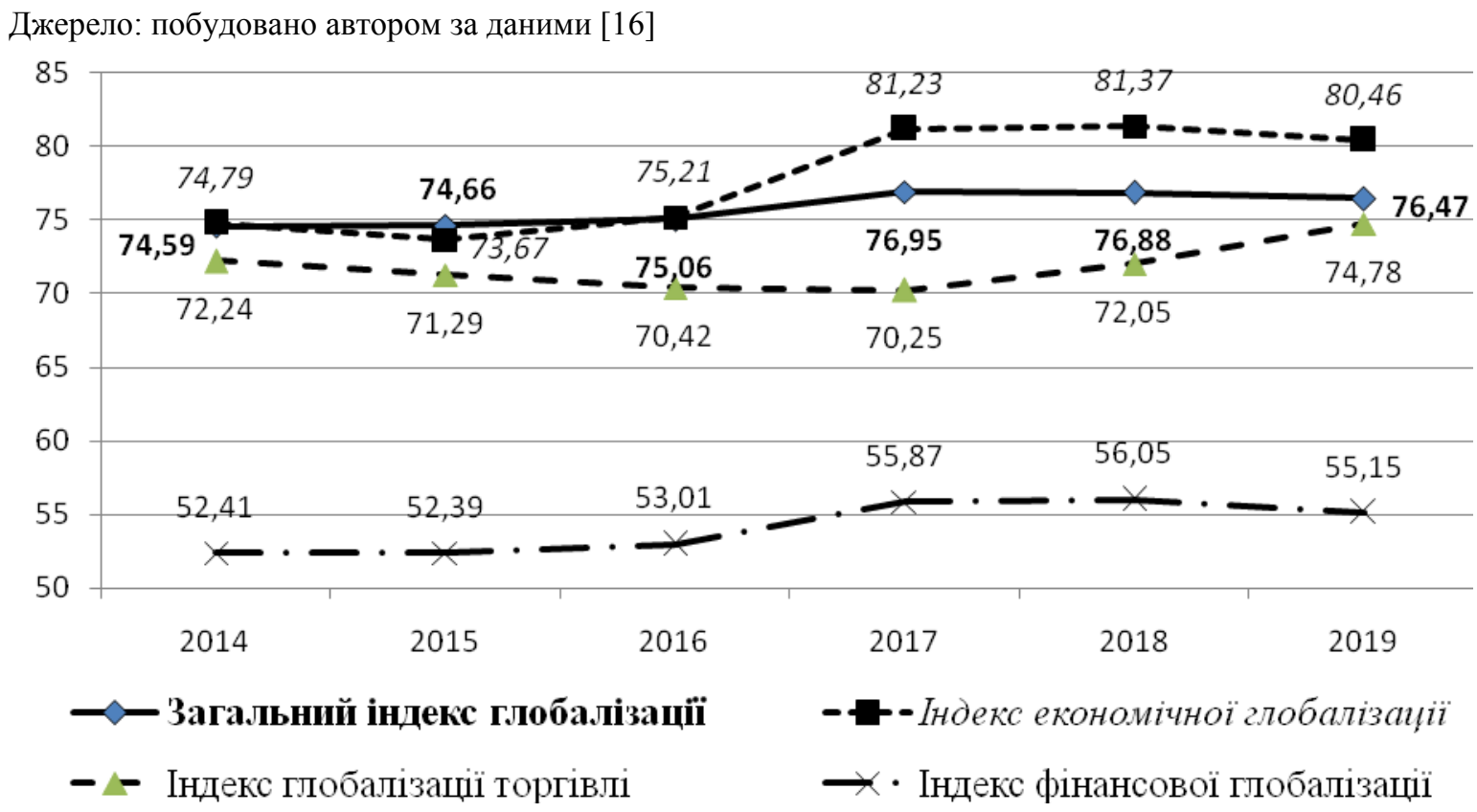

Рис. 5. Динаміка індексів та субіндексів глобалізації України

Джерело: побудовано за даними [15]

Активізація глобалізаційних процесів зумовила необхідність адаптації вітчизняної ринкової системи до світових тенденцій розвитку. Так, за висновками спеціалістів Швейцарського економічного інституту KOF, Індекс глобалізації (рис. 5) якого вимірює економічні, соціальні та політичні аспекти глобалізації національних ринків 203 країн світу [15], глобалізаційні тенденції зумовлюють активізацію розвитку внутрішніх ринків країн за рахунок зменшення транспортних і комунікаційних витрат.
Інституційне запровадження заходів дерегуляції ринкових процесів має істотний вплив на розвиток внутрішнього товарного ринку України внаслідок більш вільного руху капіталу та товарів. Загалом після 2016 р. внутрішній ринок України почав виходити 3 кризового стану, намітилися тенденції зростання ВВП (+2,3\%), показників промислового виробництва $(+2,8 \%)$, переробної галузі (+4,3\%) (табл. 4). 
Вісник Львівського торговельно-економічного університету. Економічні науки. № 62, 2021

Структура ВВП України за кінцевим використанням у 2014-2019 рр.

Таблиия 4

(млн грн)

\begin{tabular}{|c|c|c|c|c|c|c|c|c|c|}
\hline \multirow{2}{*}{ Рік } & $\begin{array}{c}\text { Номі- } \\
\text { нальний } \\
\text { ВВП }\end{array}$ & \multicolumn{2}{|c|}{$\begin{array}{c}\text { Споживчі } \\
\text { витрати }\end{array}$} & \multicolumn{2}{c|}{$\begin{array}{c}\text { Валове } \\
\text { нагромадження }\end{array}$} & \multicolumn{2}{c|}{$\begin{array}{c}\text { Експорт } \\
\text { товарів та послуг }\end{array}$} & \multicolumn{2}{|c|}{$\begin{array}{c}\text { Імпорт } \\
\text { товарів та послуг }\end{array}$} \\
\cline { 3 - 11 } & Абс. & $\begin{array}{c}\% \\
\text { ВВП }\end{array}$ & Абс. & $\begin{array}{c}\% \\
\text { ВВП }\end{array}$ & Абс. & $\begin{array}{c}\% \\
\text { ВВП }\end{array}$ & Абс. & $\%$ ВВП \\
\hline 2014 & 1566728 & 1409772 & 90,0 & 220968 & 14,1 & 770121 & 49,2 & -834133 & $-53,2$ \\
\hline 2015 & 1979458 & 1715636 & 86,7 & 303297 & 15,3 & 1044541 & 52,8 & -1084016 & $-54,8$ \\
\hline 2016 & 2383182 & 2018854 & 84,7 & 512830 & 21,5 & 1174625 & 49,3 & -1323127 & $-55,5$ \\
\hline 2017 & 2982920 & 2552525 & 85,6 & 618914 & 20,7 & 1430230 & 47,9 & -1618749 & $-54,3$ \\
\hline 2018 & 3558706 & 3196756 & 89,8 & 667953 & 18,8 & 1608890 & 45,2 & -1914893 & $-53,8$ \\
\hline 2019 & 3974564 & 3785133 & 95,2 & 500614 & 12,6 & 1636416 & 41,2 & -1947599 & $-49,0$ \\
\hline
\end{tabular}

Джерело: розраховано за даними [8]

Позитивна динаміка спостерігалась і у подальшому, зокрема у 2019 р. зростання реального ВВП становило 3,3 \%, найвагомішу роль у чому відіграло приватне споживання, зумовлене покращенням споживчих настроїв.

Висновки i перспективи подальших досліджень у даному напрямі. Проведене дослідження засвідчило низку соціально-економічних дисбалансів розвитку внутрішнього ринку України у 2014-2019 рр., які спричинили до бюджетного дефіциту, банківської кризи та зниження платоспроможного попиту. Попри деіндустріалізацію i переважання агропромислового сектору у вітчизняній економіці, інкорпорування фундаментальних правил СОТ дозволило розширити внутрішній ринок для низки секторів послуг. Разом $з$ тим, інституційні фактори впливу на ефективність функціонування внутрішнього ринку використовуються недостатньо ефективно, зокрема низький ступінь державної підтримки інвестиційної активності підтверджується слабкими позиціями України у міжнародних рейтингах. Натомість приєднання України до програми ООН "Цілі Сталого Розвитку 2016-2030" і певна трансформація інституційних засад соціального забезпечення, спрямована на подолання бідності і зростання рівня доходів населення, зумовила тенденцію помірного зростання системи соціальної безпеки. Серед розроблених за сприяння Світового банку і МВФ інституційних програм реформування найбільший позитивний вплив на розвиток внутрішнього ринку мали відмова від валютного регулювання, податкова консолідація, вдосконалення управління державними інвестиціями, персоналізація соціальної підтримки, спрощення умов ведення бізнесу, запровадження податкових методів антикризового регулювання. Завдяки цьому внутрішній ринок почав виходити 3 кризового стану, спостерігаються тенденції зростання ВВП та показників промислового виробництва. Подальші дослідження доцільно скерувати на детальний аналіз інституційних інструментів активізації внутрішнього ринку України.

\section{ЛІТЕРАТУРА}

1. Верховна Рада України. Про ратифікацію Угоди про асоціацію між Україною, 3 однієї сторони, та Європейським Союзом, Свропейським співтовариством 3 атомної енергії і їхніми державами-членами, 3 іншої сторони: Закон України № 1678-VII від 16.09.2014 [Електронний pecypc]. - Режим доступу: https://zakon.rada.gov.ua/ laws/show/1678-18\#n2.

2. Громов В. Б. Механізм формування споживчого попиту в економіці України / Громов В. Б. // Формування ринкових відносин в Україні. 2018. - № 7-8. - С. 57-67.

3. Державна служба статистики України [Електронний ресурс]. - Режим доступу: http://www.ukrstat.gov.ua/.

4. Іляш О. І. Стратегія та засоби конвергенції системи соціальної безпеки України та СС / Іляш О. І., Васильців Т. Г., Лупак Р. Д. // Бізнес Інформ. - 2018. - № 23 (491). - С. 8-14.

5. Кабінет Міністрів України. Про затвердження плану заходів на 2020 рік з реалізації Стратегії подолання бідності: Розпорядження від 03.03.2020 № 202-p. [Електронний ресурс]. - Режим доступу: https://zakon.rada.gov.ua/laws/show/2022020-\%D1\%80\#Text.

6. Колеснікова К. С. Перспективи розвитку інфраструктури ринку споживчих товарів / Колеснікова К. С., Руденко Т. С. // Розвиток торгівлі та підприємництва в Україні: тенденції та перспективи : збірник наукових праць за матеріалами міжнародної науково-практичної конференції (Одеса, 25-26 травня 2017 р.). - Одеса : OTEI KHTEУ, 2017. - 124 c. - C. 47-49.

7. Міністерство економічного розвитку i торгівлі України. Цілі сталого розвитку: Україна. Національна доповідь. [Електронний ресурс]. Режим доступу: http://un.org.ua/images/ SDGs_NationalReportUA_Web_1.pdf.

8. Міністерство фінансів України. Валовий внутрішній продукт (ВВП) в Україні 2020. [Електронний ресурс]. - Режим доступу: https://index.minfin.com.ua/ua/economy/gdp/. 


\section{Herald of Lviv University of Trade and Economics. Economic Sciences. № 62, 2021}

9. Податковий кодекс України. Редакція від 10.12.2020. [Електронний ресурс]. - Режим доступу: https://zakon.rada.gov.ua/ laws/show/275517\#Text.

10. Попадинець Н. М. Регіональний ринок споживчих товарів: сутність і засадничі положення функціонування / Попадинець Н. М. // Регіональна економіка. - 2017. - № 1. - С. 17-22.

11. Уманців Ю. М. Розвиток внутрішнього ринку споживчих товарів України / Уманців Ю. М., Катран М. В. // Бізнес Інформ. - 2017. - № 8 (475). - C. 271-275.

12. Халілов А. Е. Статистика системи споживання в регіонах України / Халілов А. Е. // Вісник ХНАУ ім. В. В. Докучаєва. Серія : Економічні науки. - 2019. - № 1. - С. 171-178.

13. Чорна М. В. Особливості формування нового ринкового простору на вітчизняному споживчому ринку / Чорна М. В., Бугріменко Р. М., Остін 3. // Бізнес Інформ. - 2019. - № 1 (492). C. 241-248.

14. Яхно Т. П. Соціалізація економіки та індивідуалізація споживчого ринку як необхідні передумови національного розвитку / Яхно Т. П. // Вісник Сумського національного аграрного університету. Серія : Економіка і менеджмент. 2019. - Вип. 2. - С. 12-17.

15. The KOF Globalisation Index / Savina G., Haelg F., Potrafke N., Sturm J.-E. Revisited // Review of International Organizations. - 2019. - Vol. 14(3). P. 543-574.

16. World Bank Group. DoingBusiness-2020. Ukraine: Reforming to Create Jobs, 2020. URL: https://www.doingbusiness.org/content/dam/doing Business /country/u/ukraine/UKR.pdf.

\section{REFERENCES}

1. Verkhovna Rada Ukrainy. Pro ratyfikatsiiu Uhody pro asotsiatsiiu mizh Ukrainoiu, z odniiei storony, ta Yevropejs'kym Soiuzom, Yevropejs'kym spivtovarystvom $\mathrm{z}$ atomnoi enerhii i ikhnimy derzhavamy-chlenamy, z inshoi storony: Zakon Ukrainy № 1678-VII vid 16.09.2014, available at: https://zakon.rada.gov.ua/laws/show/1678-18\#n2.

2. Hromov, V. B. (2018), Mekhanizm formuvannia spozhyvchoho popytu v ekonomitsi Ukrainy, Formuvannia rynkovykh vidnosyn v Ukraini, № 7-8, s. 57-67.

3. Derzhavna sluzhba statystyky Ukrainy, available at: http://www.ukrstat.gov.ua/.

4. Iliash, O. I. Vasyl'tsiv, T. H. and Lupak, R. D. (2018), Stratehiia ta zasoby konverhentsii systemy sotsial'noi bezpeky Ukrainy ta YeS, Biznes Inform, № 23 (491), s. 8-14.
5. Kabinet Ministriv Ukrainy. Pro zatverdzhennia planu zakhodiv na 2020 rik z realizatsii Stratehii podolannia bidnosti: Rozporiadzhennia vid 03.03.2020 № 202-r., available at: https://zakon.rada.gov.ua/ laws/show/202-2020-\%D1\%80\#Text.

6. Kolesnikova, K. S. and Rudenko, T. S. (2017), Perspektyvy rozvytku infrastruktury rynku spozhyvchykh tovariv, Rozvytok torhivli ta pidpryiemnytstva $v$ Ukraini: tendentsii ta perspektyvy : zbirnyk naukovykh prats' za materialamy mizhnarodnoi naukovo-praktychnoi konferentsii (Odesa, 25-26 travnia 2017 r.), OTEI KNTEU, Odesa, 124 s., s. 4749.

7. Ministerstvo ekonomichnoho rozvytku i torhivli Ukrainy. Tsili staloho rozvytku: Ukraina. Natsional'na dopovid'., available at: http://un.org.ua/images/ SDGs_NationalReportUA_Web_1.pdf.

8. Ministerstvo finansiv Ukrainy. Valovyj vnutrishnij produkt (VVP) v Ukraini 2020., available at: https://index.minfin.com.ua/ua/economy/gdp/.

9. Podatkovyj kodeks Ukrainy. Redaktsiia vid 10.12.2020., available at: https://zakon.rada.gov.ua/ laws/show/2755-17\#Text.

10. Popadynets', N. M. (2017), Rehional'nyj rynok spozhyvchykh tovariv: sutnist' i zasadnychi polozhennia funktsionuvannia, Rehional'na ekonomika, № 1, s. 17-22.

11. Umantsiv, Yu. M. and Katran, M. V. (2017), Rozvytok vnutrishn'oho rynku spozhyvchykh tovariv Ukrainy, Biznes Inform, № 8 (475), s. 271-275.

12. Khalilov, A. E. (2019), Statystyka systemy spozhyvannia v rehionakh Ukrainy, Visnyk KhNAU im. V. V. Dokuchaieva. Seriia : Ekonomichni nauky., № 1, s. 171-178.

13. Chorna, M. V. Buhrimenko, R. M. and Ostin Z. (2019), Osoblyvosti formuvannia novoho rynkovoho prostoru na vitchyznianomu spozhyvchomu rynku, Biznes Inform, № 1 (492), s. 241-248.

14. Yakhno, T. P. (2019), Sotsializatsiia ekonomiky ta indyvidualizatsiia spozhyvchoho rynku iak neobkhidni peredumovy natsional'noho rozvytku, Visnyk Sums'koho natsional'noho ahrarnoho universytetu. Seriia : Ekonomika i menedzhment., vyp. 2, s. $12-17$.

15. Savina G., Haelg F., Potrafke N. and Sturm J.E. (2019), The KOF Globalisation Index, Revisited, Review of International Organizations, vol. 14(3), p. 543-574.

16. World Bank Group. DoingBusiness-2020. Ukraine: Reforming to Create Jobs (2020), available at: https://www.doingbusiness.org/content/dam/ doingBusiness/country/u/ukraine/UKR.pdf.

Стаття надійшла до редакиї 10 грудня $2020 p$ 